\title{
Accountability in educational dialogue on attrition rates: Understanding external attrition factors and isolation in online law school
}

\author{
Amanda-Jane George, Alexandra McEwan \\ CQUniversity
}

Julie-Anne Tarr

Queensland University of Technology

\begin{abstract}
Australian higher education institutions have focused on attrition rates with increased vigour in light of the introduction of a new student success metric tied to attrition rates. Online programs have been of particular concern given persistently high attrition rates, being roughly double that of programs delivered either face-to-face or in blended online/face-toface mode. This study considers attrition theory as it has evolved for the online environment with particular reference to the role of external risk factors such as employment, and internal factors, such as social integration. The study presents data from a 2018 survey of students enrolled in a fully online law school program at an Australian university $(n=203)$. The data reveals a cohort with an array of external attrition risk factors, who are not only time poor but experience a strong sense of isolation. The study contributes to the attrition literature by providing insights into effective educational design and delivery aimed at student retention.
\end{abstract}

\section{Implications for practice or policy}

- Online program convenors ought to consider the attrition risk factors at issue in their cohort before designing comprehensive retention initiatives and plans.

- Instructors ought to consider external attrition factors, such as family and employment demands, when selecting and designing student assessments.

- Instructors ought to realistically appraise retention initiatives, such as social media initiatives, to address internal risk factors of perceived isolation and institutional commitment.

Keywords: online legal education, attrition risk factors, social integration, isolation, qualitative

\section{Introduction}

Student attrition in tertiary education is a topic of enduring relevance for educational practice and policy. For pedagogical practice, student retention is intrinsically linked to quality of teaching and educational design. In terms of policy, the Australian Government's introduction of performance-based metrics for funding has imbued the issue of attrition with a sense of urgency. From 2020 onwards, 20\% of higher education funding will be tied to student success, measured according to adjusted attrition rates (Expert Panel on Performance-Based Funding, 2019; Tehan, 2019). It is within this policy dynamic that Australian universities are making concerted efforts to address the causative factors for student attrition.

To date, tertiary education institutions have dealt with student retention in a less than uniform manner. Despite individual educators developing successful initiatives, few attempts have been made to collate and integrate individually designed strategies into a well-planned, comprehensive whole (Department of Education and Training [DET], 2017, p. 7). This paper reports on preliminary work undertaken by an Australian online law faculty aimed at understanding the attrition factors faced by an online undergraduate law student cohort, with the aim of informing the design of theoretically grounded and evidence-based retention strategies. 


\section{Background}

\section{Attrition in Australia's tertiary education sector}

Several recent Australian studies have investigated the factors leading to attrition in tertiary education. In 2017, the Tertiary Education Quality and Standards Agency (TEQSA) examined attrition in a cohort of students who commenced study one year that did not return to study the following year, nor complete their study. The study identified external enrolment or online study mode, and part-time enrolment (less than full-time study load), as influential variables. Online study was the most significant factor (TEQSA, 2017, p. 14). Online learners were around 2.5 times more likely to withdraw than face-to-face students (TEQSA, 2017 , p. 15). Cherastidtham and Norton's (2018) study of non-completion in bachelor degrees also found part-time enrolment was a significant attrition factor. In fact, studying part-time, as a mature aged student, and in the online mode, constituted an attrition risk trifecta (Cherastidtham \& Norton, 2018, p. 13).

Given the risks noted above, there have been calls for significant improvement in online student support (DET, 2017, p. 27). While there have been reported improvements in attrition rates (Department of Education, 2019), external students continue to drop out (43.6\%) at twice the rate of face-to-face $(20.4 \%)$ or blended learners $(22.9 \%)$ (Figure 1$)$. Similar attrition risk factors to the trifecta (part-time, mature aged, not on campus) are found in attrition theory (Bean \& Metzner, 1985; Rovai, 2003). In the next section we situate the present study within attrition theory literature.

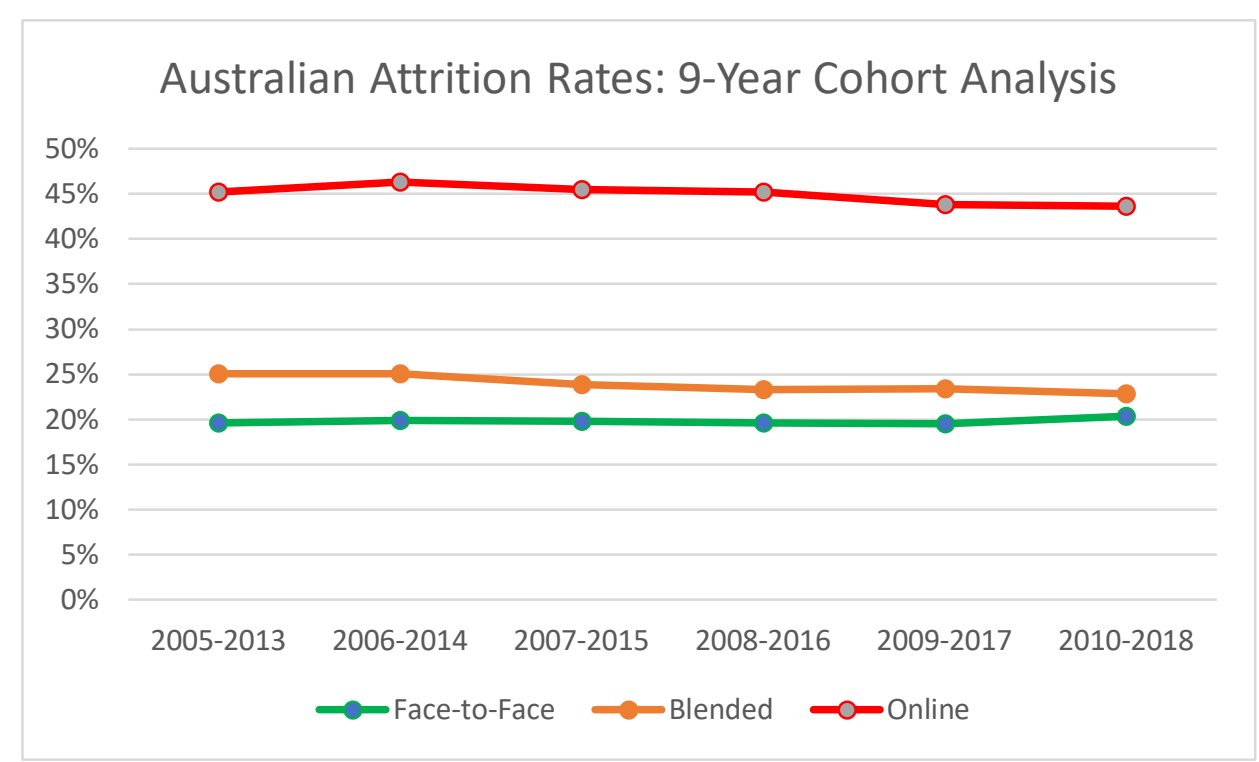

Figure 1. Australian attrition rates: 9-year cohort analysis

\section{Models of student attrition}

In seeking to understand the decisions taken by individuals in the context of their interactions with institutional social systems, this study builds on Spady's (1970, 1971) model of drop out and Tinto's (1975) student retention model. These foundational models drew on Durkheim's (1951) theory of suicide, which posits a higher risk of suicide for individuals who are insufficiently socially integrated (Spady 1970; 1971; Tinto, 1975, pp. 91-92). Given that, analogically, suicide and attrition both involve a person removing him/herself from a particular social realm, Durkheim's ideas have been widely adopted in retention studies and models (Alijohani, 2016, p. 4).

Spady (1970, 1971), drew on Durkheim (1951) to argue that poor performance in academic systems, combined with inconsistent relational support, may lead to attrition. Spady also posited that attrition decision-making was a complex social process of student-institutional interaction influenced by four main factors: (1) grades, (2) intellectual development (within the academic system), (3) friendship support, and (4) normative congruence (within the social system) (Alijohani, 2016; Spady, 1970, 1971). 
Tinto (1975, 1994), building on Spady (1970, 1971), suggested student determination to persist at an institution arose from personal characteristics, as well as a dual commitment to the institution, and to college completion. Student commitment levels depended on integration with two internal college systems: academic and social. Academic integration involved intellectual development and grade performance. Social integration developed through interactions with peers, faculty members, and administrative personnel. Varying levels of integration could lead to a re-evaluation of commitment, and ultimately to a decision either to persist, or drop out (Tinto, 1975, p. 103). In this model, the effect of factors external to the college environment, such as employment, were measured indirectly by fluctuations in the student's overall goal and institutional commitment (1975, p. 98).

Bean and Metzner (1985) remodelled Tinto's (1975) work around traditional on-campus college cohorts to address non-traditional students: mature (over 24), not on-campus (commuter), part-time, or a combination of these factors. Their model specified four main variables: (1) academic performance, (2) intent to leave, (3) background, and (4) external or environmental factors (finances, employment hours, family, and support systems). Non-traditional students were found to be largely uninfluenced by an institution's internal social environment. Their pre-existing social and support network remained largely unchanged and independent of the institution; academic offerings were of more concern. External factors, by contrast, had a direct effect on student decisions about dropping out. Indeed, external factors were more important than academic variables; even where a student's grades were good, if external variables were poor, students would leave college (Bean \& Metzner, 1985, pp. 490-1).

Kember's $(1989,1995)$ model for student attrition in the distance learning context also drew on Tinto's (1975) work regarding student characteristics, and social and academic integration. However, in focusing on external variables, this model echoed Bean and Metzner's work. Kember asserted that Tinto's (1975) concept of social integration was "not directly transportable to distance education" (1989, p. 294). Instead, for distance education students he saw social integration as a student's ability to integrate study with external factors of family, work, and (non-institutional) social commitments. Yet, it must be remembered that Kember's (1989) dismissal of internal/institutional social integration occurred at a time at which there was limited technology available to facilitate synchronous peer communication. Online platforms such as Zoom, social media, and university learning management systems have burgeoned since then.

Rovai's (2003) composite persistence model for online education incorporated features from Tinto (1975), and Bean and Metzner (1985). With regard to external factors, Rovai (2003) drew on Bean and Metzner (1985), and included financial considerations, work, family, and outside encouragement. For internal factors, Rovai (2003) drew on Tinto (1975), and included academic and social integration, goal commitment, institutional commitment, and the learning community. Importantly, Rovai's (2003) model retained Tinto's (1975) concept of social integration with the student's institution. Hence, with the evolution of technology, attrition theory evolved to take account not only of the considerable impact of external attrition factors for the online student, but also the internal factor of social integration.

\section{Online students, learning, and social integration}

Rovai's (2003) inclusion of social integration in online attrition theory complements social constructivist theories of online education, as it supports the idea that social interrelations play a key role in the student's online learning experience (Rovai, 2002; Garrison et al., 2000). Constructivist pedagogy encourages active design elements (learner-directed and paced, small group work, different activities) with a collaborative focus (teams, heterogeneous groups), emphasising integration between theory and practice (Voogt, 2003, p. 222; Voogt, 2008). The flipped classroom model (Bergmann \& Sams, 2012; Cheng et al., 2019; Lage \& Platt, 2000; Lage et al. 2000; Sun et al., 2018; Zhai et al., 2017) aligns well with constructivist theory, and is typically used in online higher education. Instead of live, synchronous lectures, didactic work is done asynchronously, via instructional videos and supporting material. The student then attends synchronous, teacher-facilitated online workshops, where collaborative activities assist students "to understand, apply, analyse, evaluate, and create" new knowledge (Cheng et al, 2019, p. 795).

If it is accepted that social factors influence a student's attrition decision-making, and are important to effective online learning, it follows that online students face significant challenges. By definition, online learning occurs in the absence of physical co-location, with its opportunities for meaningful, in-person interaction with faculty members, peers, and administrative staff. Online flipped learning makes further 
demands of the student: it requires significant levels of self-direction, motivation, and the ability to apply help-seeking strategies (Lewis, 2019; Sun et al, 2018). Self-directed learning may be challenging, especially where students have enrolled online out of necessity, rather than choice - they may not be the autonomous distance learners theorised by Moore in the 1970s (Moore, 1973; Rush, 2015). As to help-seeking strategies, institutions often find it difficult to ensure that students who need support actually take up the services on offer (DET, 2017, p. 25). This problem may be compounded if lecturers do not provide sufficient teaching presence (Garrison et al., 2000, p. 96), for example, via instruction emails and adequate feedback or guidance (Rush, 2015; Sun et al, 2018).

Several studies have identified a sense of isolation or otherness as a flow-on effect of online learning circumstances (Bawa, 2016; George et al., 2018; Milheim, 2012; Rovai, 2002; Rovai \& Downey, 2010 Rush, 2015). Some students, for example those who are the first in their family to enter tertiary study, may be particularly affected by isolation (Stone \& O'Shea, 2019, p. 61). Rush's (2015) study identified isolation and disconnection as key indicators of online student dissatisfaction, lending support to Tinto's (1975) theory that increased social integration lowers attrition risk. It appears that fostering and supporting connectedness is central to both the online learning experience and to reducing attrition risk. The question remains, however, as to the strategies best able to achieve this in the online learning environment. Recent research has demonstrated positive effects on attrition rates by utilising university-sponsored social media and learning management systems, although the effect size was small and the study had various limitations (Eaton, 2019, p. 99).

While isolation in online education presents a challenge, the nature and extent of attrition factors facing online law students has gained little attention. In Australia, law students are recognised as having particular vulnerabilities. Evidence indicates psychological distress levels to be negatively correlated to law students' perceived lack of belonging (Skead and Rogers, 2014, p. 575-576), and that law students' distress levels are higher than, for example, medical students or the general population (Kelk et al, 2010, p. 116). In addition to the lack of understanding of attrition factors for online law students, it is unclear as to whether there is a link between online law students' experience of social isolation and high rates of attrition. The present study was designed as a preliminary step in developing a broad understanding of attrition risk factors, including isolation, in this cohort.

\section{Rationale, aims, and method}

The CQUniversity law program is a small, completely online undergraduate law school with 1774 currently enrolled students. Teaching is conducted in flipped classroom format, with unit materials available for download at the commencement of term. The core unit content is regulated by the accrediting bodies responsible for admitting lawyers into practice in Australia. As such, lecturers do not have absolute freedom in designing unit material, which typically includes weekly video lectures, readings, and problem questions designed to encourage the students to apply their knowledge to a legal problem scenario. These problems are discussed in the weekly synchronous workshops with the lecturer and peers. Attendance at these workshops is not mandatory; many students access the workshop content via recordings. All units have learning management system-facilitated discussion fora, which are sometimes assessed, but more often used for formative work or informal communication. Group work is assessed in some units, although most lecturers set individual written assessments, such as problems and quizzes, or video submissions.

This study evolved from a 2017 project that explored Facebook as an adjunct to the institution's learning management system (Moodle). Its aim was to address the students' (assumed) low level of social integration, which is an internal attrition risk (Rush, 2015; Tinto, 1975). The results for students in an undergraduate law unit $(n=27)$ suggested social media has a role in supporting an online learning community, and fostering peer and lecturer connection (George et al., 2018). These results were encouraging, lending support to studies on the use of social media in building a sense of connection (Eaton, 2019; Sadowski et al., 2017).

When considered more broadly, however, the attrition issue requires a high level of accountability on the part of institutions and educators to better understand their students' online learning experience. Gaining an insight into the drivers of online study and its perceived benefits provides an opportunity to identify and strengthen positive elements of the program. Further, understanding the students' perspective may assist in identifying attrition risk factors and designing appropriate responses. Also, while the Facebook trial proved 
effective in one class, we knew very little about the nature of student isolation, in terms of disconnection from peers, faculty, or institution (Tinto, 1975). Hence, a better understanding of the strengths and weaknesses of online study, including any student isolation, appeared to be a prerequisite for the evaluation of social media use, and understanding how to position social media within a more comprehensive retention strategy (DET, 2017, p. 7). The present study was therefore guided by three research questions:

1. How does this cohort perceive the strengths, and the challenges or weaknesses, of online legal study?

2. If isolation emerges as a perceived weakness or challenge, what is the nature of the isolation (disconnection from peers, lecturers, and/or the university)?

3. How can this student-based understanding of the strengths and weaknesses of online legal study inform a holistic, faculty-wide retention strategy?

A study questionnaire employed Likert-scale questions (Lewis-Beck et al., 2004) to obtain demographic information and levels of student connectedness according to Tinto's (1975) dimensions of social integration: peers, faculty, and institution. Open-ended questions obtained data on the students' perceived strengths and weaknesses of studying law online (see Appendix A for the survey tool). These questions drew on Rush's (2015) relatively large-scale study investigating the experience of distance education in a cohort of tertiary students in Australia. Three of Rush's (2015) questions were integrated into the questionnaire:

- What do you think is the best aspect of being a distance student?

- What do you think is the worst aspect of being a distance student?

- What would make distance learning better for you?

The phrase "best aspect" aimed to elicit responses related to the strengths of online study and the "worst aspect" aimed to elicit responses related to the weaknesses or challenges involved in online legal study. The study had Research Ethics Committee approval (ID 21211).

Data were analysed according to reflexive thematic methods, involving an "organic and open iterative process" of identifying meaning-based patterns across the dataset (Braun et al, 2019, p. 848). The initial coding was guided by the Rush (2015) coding. During the iterative process of analysis, coding was shaped by the themes that emerged from this study's data (see Appendix B for the coding schemas for the above three questions, and variations from Rush's (2015) coding). Due to resource constraints, one person conducted the coding process. Coding decisions were documented in NVivo memoranda, to support reflections and analysis (Bazeley and Jackson, 2013, p. 93; Creswell \& Miller, 2000, p. 128). To optimise reliability, emergent themes and the coding process were subject to regular peer debriefing (Corbin \& Strauss, 2008, p. 299; Creswell \& Miller, 2000, p. 129).

Two forms of NVivo analysis were employed. First, a word cloud was generated for each question, to provide an easy-to-interpret visual depiction of the word frequency tabulation; the larger the font size, the more frequently a word was used by respondents. This method is useful as a learning tool, and for summarising interviews (Filatova, 2016; Miley and Reid, 2011). Cluster analyses were also performed. Clustering defines groups of cases by mapping similarities or dissimilarities on multiple dimensions (Aldenderfer and Blashfield, 1984). In NVivo, nodes (coded themes) with similar words are clustered more closely, suggesting a closer thematic relationship. Pearson correlation coefficient was applied (ranging from -1.0 to +1.0 , where +1.0 indicates strongest correlation between clusters).

Links to a SurveyMonkey online survey were emailed to all undergraduate students enrolled in the online law program at CQUniversity via a Moodle page during June and July $2018(n=1319)$ and November 2018 $(n=1412)$. We received approximately a $15 \%$ response rate $(n=203)$, which is comparable to Rush's (2015) study (approximately 17\%). Testing indicated a relatively representative sample across year levels, although some bias towards first year students was evident $(M=37.5, S D=6.45$; removing first year outlier $M=35, S D=3.53$ ). We were unconcerned with the bias towards early-program students, given that both normal and adjusted attrition rates are measured by commencement in Year 1 and failure to re-enrol in Year 2, or transfer (DET 2017, p. 36), although cohort analyses include drop outs at later years and overall failure to complete (Department of Education, 2019). 


\section{Results}

The statistical data provided demographic information for the respondents, allowing identification of the various attrition risk factors, particularly age and part-time enrolment (Cherastidtham and Norton, 2018). The statistical information also gathered data on external attrition factors, such as work and family commitments (Bean and Metzner, 1985), location, and first-in-family status (Stone \& O'Shea, 2019). The qualitative data addressed students' reasons for choosing online study (drivers), and the best and worst aspects of online study, and how to make it better (Rush, 2015).

\section{Statistical data}

All respondents $(100 \%)$ studied law online. The majority $(75.5 \%)$ were mature age students, that is above $18-24$ and below the 55 to 64 age bracket. There were significantly more part-time $(66.5 \%)$ than full-time $(33.5 \%)$ students. Thus, most students exhibited the attrition risk factor trifecta.

As to external risk factors, most students (80.8\%) were employed; almost one third (31.9\%) worked between 30-39 hours a week and, surprisingly, more than one third (35.4\%) worked more than 40 hours per week. Almost two thirds of respondents $(64.6 \%)$ had 1-2 dependents. The extent of external demands on time came through clearly in the themes that emerged from the qualitative data, as discussed below.

Students' geographic locations were consistent with CQUniversity's roots as a regional Australian university. Almost one in five students (19.5\%) lived in a rural, remote, or very remote region. Half the students lived in regional cities (51.4\%) and less than one third (29.2\%) lived in an Australian capital city. More than half of students $(53.2 \%)$ were first in family to study at tertiary level.

One of the significant questions in the statistical section of the survey was: "If you had your choice again, would you choose to study law on campus in traditional face-to-face lecture mode?". Although just under $80 \%$ of students indicated they would study online again, this result should not be interpreted as a proxy for student satisfaction. Responses to the open-ended questions indicated that most students felt they did not have the freedom to choose their mode of delivery. As one respondent noted: "[The question on choice] is misleading. There is no choice, I cannot study full time unless I move to a different city and leave my job and business and have my husband find a new job and buy a new home!” (Respondent 45).

This perceived necessity, in a cohort with a high prevalence of the risk trifecta (fully online, part-time, mature age) and compelling external risk factors (work, family), suggest the law program faces significant risks of attrition (Bean and Metzner, 1985). With regard to Tinto's (1975) internal attrition risk factor of social integration, respondents rated their connection to the institution, peers and lecturers. Most respondents $(n=179 ; 88.1 \%)$ skipped the question on connection to the institution. Over one half of students $(54.6 \%)$ indicated they felt not connected at all or only a little bit connected to peers. Forty percent indicated they felt either not connected at all or a little bit connected to lecturers. The themes of necessity due to external factors, and lack of connection or internal factors, were supported in the responses to the open-ended questions as discussed in the next section.

\section{Reasons for choosing to study law online}

Question 19 asked students $(n=181)$ about their reasons for choosing to study law online. The two largest nodes (coded themes) to emerge from responses were necessity and flexibility. The necessity node $(n=$ $170 ; 93.9 \%$ of respondents) was almost double the size of the flexibility node $(n=86 ; 47.5 \%)$. The sheer size of the necessity node confirms the overwhelming majority of students felt they had little real choice in studying online. Work was the primary driving factor for the perceived necessity to study online (41.4\%), accessibility/location was second (21.5\%), and family was third (14.4\%).

Word frequency analysis showed that work was clearly foremost in students' minds as the driver for online study (Figure 2). Cluster analysis revealed almost exact correlations between the nodes of necessity and work commitments (0.951), and between the nodes flexibility and self-paced, time management (0.916). The necessity and flexibility nodes were also correlated moderately strongly (0.668), suggesting similar themes underpinning these nodes. While clustering showed a strong positive correlation between the 
necessity and family commitments (0.831) nodes, work clearly emerged from all analyses of Question 19 data as the most significant external factor driving respondents to study online.

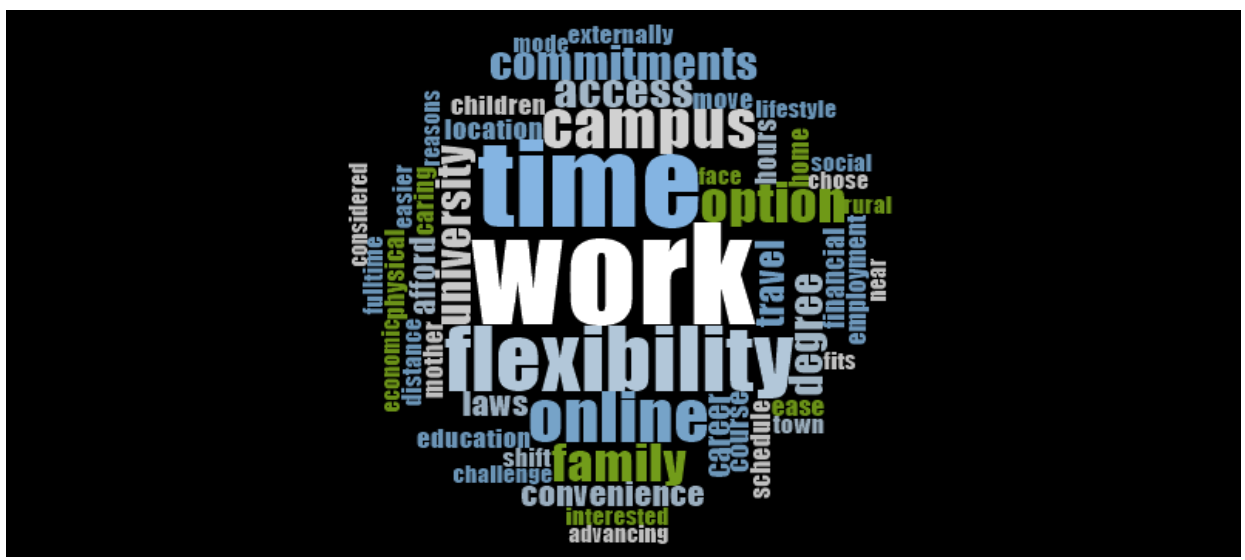

Figure 2. NVivo Word Cloud for Question 19

\section{Best aspect of being a distance student}

Question 26 asked students $(n=174)$ to nominate the best aspect of being a distance student. The question was included in the Rush (2015) study and was designed to provide a point of broad comparison. The largest node in the CQUniversity study, by a considerable margin, was flexibility. On average, each respondent coded at least once to the child nodes (nested within this parent node) $(105.2 \%)$, mostly the time, convenience node (61.5\%). Similarly, Rush's (2015) largest node (50.5\%) was convenience, time or flexibility.

Consistent with Question 19, in both the CQUniversity and Rush (2015) studies, more than one third of respondents indicated some aspect of necessity when discussing the best aspect of online study (CQUniversity 41.4\%; Rush 37.4\%). Rush (2015) found more than one third of students coded at either work or family, and $18 \%$ coded for both. In the CQUniversity study, more than a quarter coded at either work (17.8\%) or family (9.7\%), and 18.8\% coded for both. The results for Questions 19 and 26 thus provide complementary perspectives on the same issue: the main driver for choosing online study was to accommodate life's necessities, mainly work (Question 19), and the best aspect of online study was the flexibility to schedule study time around external factors, mainly work (Question 26). Word frequency analysis showed that these time-poor students placed a premium on the time benefits associated with online study (Figure 3).

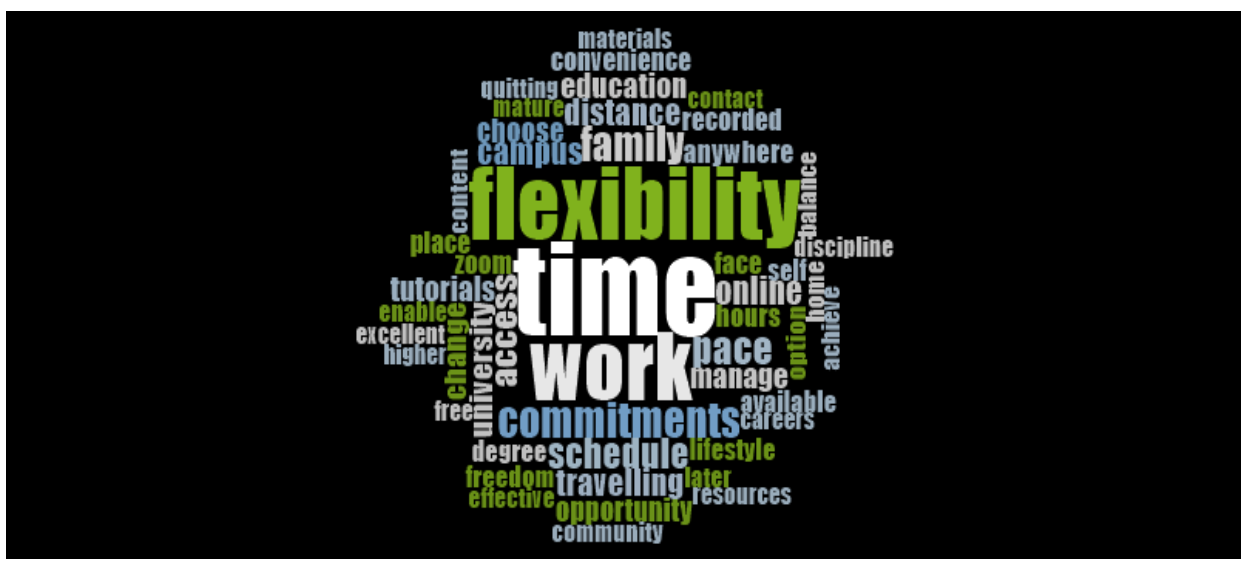

Figure 3. NVivo Word Cloud for Question 26

NVivo cluster analysis showed an almost exact correlation between the nodes of necessity and work time (0.976), and flexibility and time, convenience (0.945). The nodes of necessity/work time and flexibility/time, convenience were also moderately strongly correlated (0.685), again indicating similar themes underpinning these nodes. Comments included: "[The best] aspect of being a distance student is 
that I can study in my own time whilst working full time. Without this option, I just would not have been able to complete a degree" (Respondent 28).

\section{Worst aspect of being a distance student}

Question 27 asked respondents to nominate the worst aspect of being a distance student $(n=174)$, which the Rush (2015) study also included. The largest node for this question was isolation. On average, each respondent was coded more than once to the various child nodes in the largest isolation parent node (112.1\%), mostly disconnection (74.7\%). Isolation in the sense of feeling disconnected was also the largest node in Rush's (2015) study (68\%), although that study did not investigate the different aspects of disconnection.

Given the more detailed coding in the CQUniversity study, guided by Tinto's (1975) dimensions of connection in social integration (lecturers, peers, institution), more granular results were generated. Respondents were coded more for peer disconnection (43.7\%) than lecturer disconnection (14.9\%). For peers, coding indicated respondents felt study-related disconnection (10.9\%) more than social disconnection (8.6\%). These results support Bean and Metzner's contention that academic matters, rather than informal socialising, are more important for non-traditional students. The university was mentioned infrequently $(2.9 \%)$. Other significant nodes for worst aspect were responsibility - self-motivation, engagement, self-discipline (CQUniversity 19.5\%; Rush 10.7\%), and feeling unconsidered - unable to selfpace due to group work, scheduling difficulties (CQUniversity 15.5\%; Rush 14.5\%). Word frequency analysis in Figure 4 confirmed (lack of) connection was the worst aspect of online study:

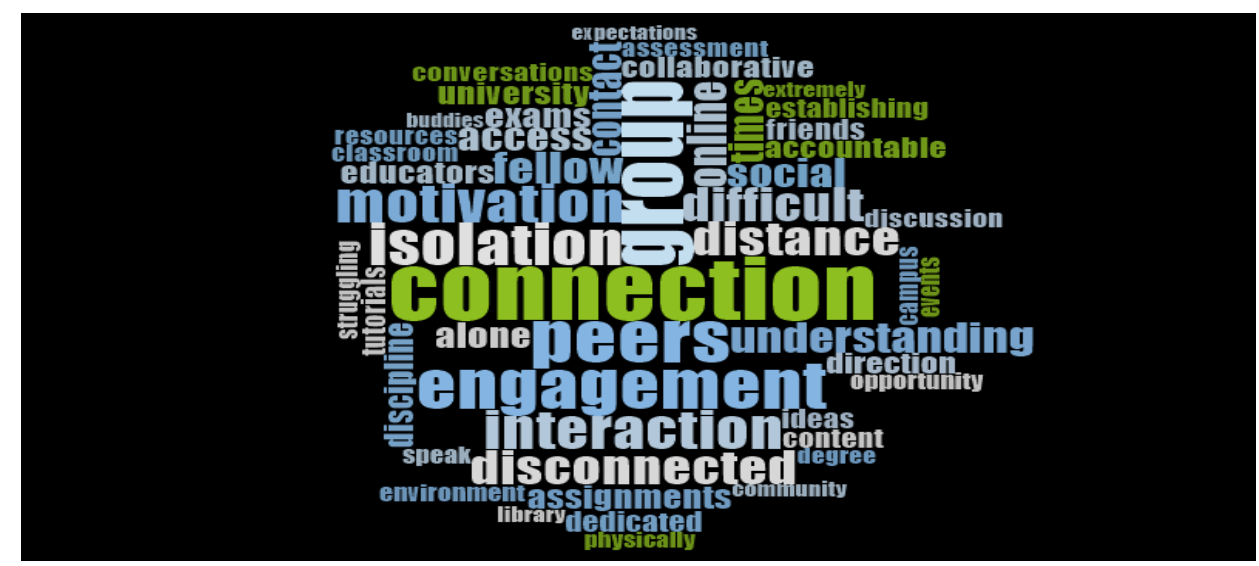

Figure 4. NVivo Word Cloud for Question 27

NVivo cluster analysis provided additional insights. Two striking themes emerged: isolation from peers, and feeling unconsidered.

\section{Isolation from peers}

In terms of Tinto's (1975) benchmarks, isolation from peers was predominant. The isolation and disconnection nodes correlated exactly (1.0); both isolation and disconnection correlated exactly with disconnected-peers (1.0). Isolation correlated moderately with disconnected-lecturers (0.701), but isolation was almost uncorrelated with disconnected-uni (0.104). This clustering, consistent with the peer node size $(n=76 ; 43.7 \%)$, demonstrated the same themes underpinned the respondents' feeling of isolation and their lack of opportunity to interact with peers. Comments included: "Law is all about being able to communicate your case yet we are stripped from that possibility. Studying alone for hours on end and wishing you could call someone for help if in the need" (Respondent 113). One student observed: "As we are basically all looking for the flexibility of our own time, coinciding with other students online at the same time is infrequent" (Respondent 133). Such comments, and further results for Question 28 discussed below, indicate that the results on disconnection and isolation must be considered with some caution.

\section{Feeling unconsidered}

Of note for this cohort was a strong correlation between the nodes unconsidered and not being able to selfpace, scheduling (0.939), and a moderately strong correlation between the latter and invigilated exams 
(0.709). CQUniversity has introduced more invigilated examinations into the law curriculum to satisfy requirements imposed by the legal profession accreditation body. Results indicate these changes impacted heavily on remote, rural and regional students, requiring them to travel significant distances to sit an invigilated examination at a designated centre. Comments included: "Being a DISTANCE student! I have to travel $200 \mathrm{kms}$ to attend examinations which means an overnight stay when exams commence early; this is costly and inconvenient" (Respondent 34) and "Invigilate[d] Exams - really difficult to manage in a full time work week" (Respondent 32). A moderate correlation also emerged between scheduling of lecture, assignments and group work (0.663). However, group work is also mandated by the relevant professional accreditation body across several core law units.

\section{What would make distance learning better?}

Question 28 asked: "What would make distance learning better for you?" ( $n=165)$ which, again, was included in the Rush (2015) study. The two largest nodes were more contact and consideration. In the more contact node $(41.8 \%)$, where type of contact was specified, respondents mainly mentioned physical or faceto-face contact $(17.6 \%)$, and peer contact $(12.1 \%)$. Of the respondents that mentioned peer contact, more sought study-related $(4.8 \%)$ rather than social $(1.2 \%)$ contact. In the consideration node almost a third $(30.3 \%)$ of students wanted greater consideration of their needs; the inconvenience of in-person invigilated exams drew significant mention $(9.7 \%)$.

Echoing the results for Question 19, word frequency analysis showed time was mentioned most frequently as a way to make distance learning better (Figure 5):

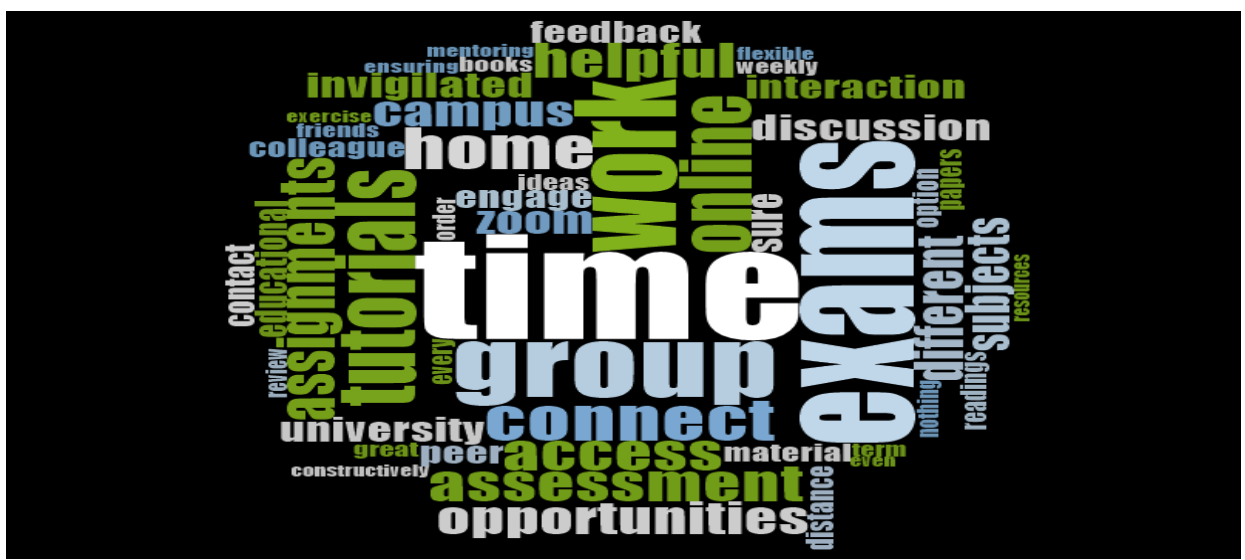

Figure 5. Nvivo Word Cloud for Question 28

Nvivo cluster analysis confirmed similar themes to Question 27: consideration issues and peer interaction.

\section{Consideration issues}

The consideration node strongly correlated with exams (0.790). This clustering was also consistent with Question 29, which invited any other comments, where the negative aspect of invigilated exams again drew the largest number of comments $(8 \%)$ and strongest correlation with student appeals for improvement (0.812).

\section{Peer interaction}

Similar to Question 27, both the nodes of more contact and more interactions correlated exactly with more student interaction (1.0). There was also closer clustering with study-focused (0.870) than social interaction (0.377). Comments included: "Having more study friends" (Respondent 195). In comparison, the nodes of more contact and more interactions had almost no correlation with more lecturer interaction $(0.054$ for both).

The results for both Questions 27 and 28 suggest that a higher level of peer study-group contact would improve distance learning for this cohort, lending support to the emphasis on peer social integration in Tinto's (1975) and Rovai's (2003) models of attrition. However, the CQUniversity students were more focussed on academic rather than informal/social connection, as was identified in Bean and Metzner's work 
with non-traditional students. The challenge in addressing this issue is that time poverty within this student demographic may make participation in study groups practically difficult.

\section{A cautionary note on peer social integration}

While the above results on peer social integration appear compelling, in light of responses obtained for Questions 24 and 21, some caution should be exercised. In the coding process for Question 24, "How connected do you feel to your student peers?" two surprising nodes emerged: (1) OK with little interaction (in the positive parent node), as well as (2) too time poor or hard (in the negative parent node). These comments represent a significant number of the overall responses to Question $24(17.7 \%$, or almost one in five). This result demonstrates that a significant number of students seem to prefer minimal interaction: "I like the fact that it is not constant interaction" (Respondent 23). They already have sufficient connections, supporting Bean and Metzner (1985): "I'm not looking for social connection from university" (Respondent 61). Also: "Online learning doesn't really allow for strong peer connections. I already have incredible friends and support, so I'm not looking to make friends at uni (of course I would love to make friends if it were to happen)" (Respondent 35).

Question 21 explored student wellbeing more broadly, asking respondents to rate their quality of life. A significant number of negative comments were recorded for Question 21 (33.5\%), especially in relation to financial issues, family, stress and health. This is consistent with the stressed nature of law students generally (Kelk at al., 2010). Of these negative comments, however, few were coded to the child node lack of social interaction, network (1.6\%). To the contrary, a sizeable positive node existed (26.9\%). Within this node, the largest child node was a positive mindset, attitude (11\%). Comments included: "You cannot give in to the spirit of despair and must never ever give up" (Respondent 61).

Thus, while isolation from peers emerged as a strong theme in Questions 27 and 28, the effect is attenuated when read together with the responses to Questions 21 and 24. Around one in five preferred disconnection; and while a third of students faced some fairly extreme challenges, these were not focused on isolation. One quarter of respondents were upbeat and positive about studying online.

The role of social media in peer social integration

Perhaps surprisingly for Question 28, which explored ways to make online learning better, the node more contact/contact-online had very little correlation with more student interaction (0.188), and even less with more lecturer interactions (0.057). Nevertheless, some comments called for more social media connection: "More facey groups I.e [sic] for every subject" (Respondent 166), and "[p]reviously there was a facebook group for Law students but it was closed down. It made the gap seem much smaller and was very much appreciated" (Respondent 25).

The comments relating to Question 28 should be interpreted together with the responses to Question 24 on connection to student peers. Of the comments in the positive node, the social media node was the third largest (8\%). Comments included: "Facebook is the biggest connection, without it I believe I would struggle to interact with other law students. However, I'm not an active poster/comment on the Facebook pages, but I do read most of the posts and comments on there" (Respondent 163). This comment supports other studies that have found that Facebook facilitates social interaction, and even passive participation has a "considerable positive effect on persistence" in college (Eaton, 2019; Fagioli et al., 2015, p. 21).

Perhaps it is the ability to access Facebook asynchronously to peers, and the ability to read posts but not respond, or to interact by simply clicking an emoji, that makes social media attractive. It allows this timepoor cohort to achieve at least some sense of peer social integration or connection, even if this is more superficial than in the face-to-face study mode. Yet it does not appear to be the panacea for student social integration initially suggested by the pilot study (George et al., 2018).

\section{Bridging the 'social integration gap': institutional commitment and lecturer connection}

If Tinto (1975) is correct and social integration plus academic integration generate institutional commitment, the students may have weak ties to their online institution. Indeed, most (88\%) students skipped the question regarding connection to the university. While academic integration is largely a reflection of internal student characteristics (Tinto, 1975, p. 104), social integration is more within the realm of institutional influence. Social integration is the product of 1) informal peer group associations, 2) semi- 
formal extracurricular activities, and 3) interaction with administrative and faculty personnel (Tinto, 1975, p. 107).

Regarding peer group associations, as noted, the students rated themselves as low in their connection to peers; isolation was the largest node for the worst aspect of online study, and more contact was the largest node for suggestions to make online study better. Yet many students only access collaborative workshops via online recordings, and they did not overwhelmingly call for more social media use. Further, the law school offers no synchronous, institutionally organised informal/social peer activities such as a law ball or sporting clubs. It offers a few semi-formal extracurricular activities, for example, regular orientation Zoom sessions for new students. However, attendances are generally low. This is likely due to time poverty and the students' heightened focus on matters more directly related to grade performance (Bean and Metzner, 1985).

As to interaction with administrative personnel, Question 18 revealed that most (53\%) do not seek out university support services and thus interact with administrative personnel. Where they do, as Bean and Metzner (1985) would predict, it was to obtain academic assistance (28\%) or mentoring (11\%). It may be that faculty interaction - Tinto's (1975) third type of interaction - accrues increased significance in developing institutional commitment. Faculty interaction may be capable of not only facilitating social integration, but academic integration as well (Spady, 1971; Tinto, 1975). As one participant in Stone and O'Shea's study put it: "The engagement demands [of online instruction] are completely different, the reliance of students on the instructor is much more intensive - basically you're it. The instructor is everything to the students" (Stone and O'Shea, 2019, p. 62). A heightened focus on faculty interaction also aligns with Bean and Metzner's (1985) contention that non-traditional students, by and large, are more focused on academic matters.

In the CQUniversity study it was significant that around $40 \%$ of students felt unconnected or only a little connected to lecturers, a quarter of students were ambivalent, and one third reported they were quite or strongly connected. Several respondents commented on the variability in lecturer connection, such as: "Some lecturers make themselves more available than others. [S]ome are slow and sporadic in replying via moodle forums and email, others are very responsive" (Respondent 21). Such comments reiterate Stone and O'Shea's (2019) findings that online educators need to be cognisant of their changing role, and the particular design and delivery requirements of the online environment and online teaching (p. 62).

\section{Discussion}

The first research question for this study was to investigate the students' perceptions of the strengths and challenges or weaknesses of online study, to identify positives as well as potential attrition risk factors. The second was to inquire as to the nature of any isolation identified by the students, and the third was to ask how the insights gained from a better understanding of the student experience could inform evaluation of retention initiatives such as Facebook groups, and enable a more holistic faculty-wide retention strategy. This section draws on these questions and the results to discuss implications for practice, policy and theory.

\section{Attrition risk factors identified}

As to the first research question, the trifecta of attrition factors was identified in the student cohort. CQUniversity respondents tended to fit the archetype of online non-traditional students: part-time, mature age, and not on campus. The formidable external demands on online students' time came through clearly in the qualitative data. For almost all respondents (93.9\%) the online mode was a necessary precondition for the decision to enrol, due to its flexibility to accommodate external factors, principally work. This was confirmed by node size, and revealed by the word frequency and cluster analyses. The corollary of the above is that students saw flexibility as the best aspect of online study, with all students coding at least once to the child nodes in the flexibility parent node, particularly time $(61.5 \%)$. Students often mentioned the need to accommodate work when discussing the benefits of online study. The need to accommodate family commitments was not as strong a driver as the need to accommodate work.

These results provide insight into the extent to which external attrition factors drive online enrolment for this cohort. Given the high number of hours spent in employment for many students, and the significant time poverty they face, there are also implications for student wellbeing. Future cross-institutional research 
could shed light on whether these results are common among online law students, and the impact on attrition.

Addressing the second research question, students reported internal risk factors around social integration: feeling unconsidered, and a strong sense of isolation. These findings have significant implications.

\section{Course and unit design implications}

The course and unit design implications, particularly from the results on feeling unconsidered, are that imposing constraints on flexibility (e.g., centrally scheduled invigilated exams, heavily weighted group work, mandatory workshop attendance) will likely cause student dissatisfaction and may impact negatively on overall commitment levels. If a student's sense of institutional commitment is already low, as these results suggest, course or unit design changes that adversely impact on external factors (particularly work) are likely to increase the risk of non-completion or transfer (Bean and Metzner, 1985; Kember, 1989).

On the other hand, the CQUniversity results on group work are in contradistinction to other studies which indicate that students like group work due to its sense of community (Trespalacios and Lowenthal, 2019, p. 69). Such differences highlight the need for accountability prior to designing retention strategies: institutions, and course convenors, cannot effectively design strategies to optimise student retention without knowing the characteristics and preferences of their own cohort (Stone and O'Shea, 2019, p. 60).

As with Rush's (2015) study, isolation was endemic in the CQUniversity cohort. However, the isolation issue appears to be more complex than Rush (2015) was able to ascertain on the basis of her study data. In answering the second research question, the present study found that students felt more isolated from peer study groups as opposed to peer informal/social groups. This finding is consistent with Bean and Metzner's (1985) observations of a heightened focus on academic matters in non-traditional students. However, the results also showed resistance to study-focused, connection-building initiatives such as group work. As noted, assessments requiring synchronous attendance impede the flexibility desired by these participants.

It appears that low or non-assessable peer study initiatives, student mentoring programs (Stone and O'Shea, 2019 , p. 64), or the creation of asynchronous student study hubs, may align more closely with online students' need to connect. Such strategies appear better placed to address this attrition risk factor. On this point, CQUniversity law school is trialling Microsoft Teams, a platform that has the look and feel of social media, but is more focused on unit content.

The study's findings also allow a more informed evaluation of the role of social media, as anticipated by the third research question. The study indicated that social media may assist in bridging the isolation gap for some students; several responses suggested Facebook was an integral part of connecting with peers. This data supports the previous pilot study (George et al., 2018) and Eaton's (2019) study. Nonetheless, as Bean and Metzner would predict, the study suggests that many "non-traditional" online students are so time poor and grade-focused that informal peer social engagement may be viewed as a luxury. Given that lecturer administration of social media sites such as Facebook requires significant hours, the results may prompt a reconsideration of the student engagement or retention return vis-à-vis lecturer, and institutional, investment. It also suggests the need for more modest expectations as to the retention return on investment for such endeavours. In sum, connecting with students via social media does not appear to be an attrition risk panacea.

\section{Policy and theory implications}

The study findings have policy implications beyond course or unit design. Indications are that the flexibility of online courses is not of itself sufficient for student retention; and retention strategies to build social integration, like Facebook, do not have overwhelming student appeal. Overall, peer isolation may be difficult to address effectively in a synchronous manner. In addition to students' increased focus on academic matters, external factors (such as work) lead to significant time poverty and problems coordinating availability. Further research is required to better understand what isolation means to law students studying online, to develop a holistic institutional approach to support mechanisms that can be implemented to meet students' perceived study partner and learning community needs. This will enable better development of Tinto's (1975) peer social integration and institutional commitment. 
The other factor in social integration is faculty interaction. The study results highlight the need to provide course convenors with suitable professional development training on working effectively in the online education setting. Such programs would include training on suitable student support strategies, student expectations, responsiveness, and curriculum design. A well-designed professional development program could form a key pillar in institutional online student retention plans. Significant attention has been focused at the macro level on professional development for school teachers to support the implementation of twentyfirst century competencies (Voogt and Roblin, 2012). Historically, at the meso-level, few Australian higher education institutions have a strong record in professional development training (Canon, 1983; Dearn et al., 2002), especially preparation for the online teaching environment - with exceptions, for example Gregory and Salmon (2013) and Wilson and Stacey (2004). However, the study suggests significant benefits were they to implement such programs.

In terms of theory development, the very low level of institutional commitment revealed by the results invites further research questions. It may prove fruitful to investigate the nature of institutional commitment in online programs, with the aim of refining or perhaps reconceptualising the role of institutional commitment in attrition theory. If institutional commitment is lower in online programs, what is it that keeps students at a particular institution? Is it largely and simply a matter of path dependence or convenience, or is it a student's internal goal of studying at a particular (well ranked or reputationally appealing) institution? (Tinto, 1975, p. 94). Or is it the lecturers who are responsible for generating much of the institutional commitment? Such research could provide valuable insights and inform the focus and effectiveness of future online retention initiatives.

\section{Conclusion}

This paper surveyed the contemporary tertiary education attrition landscape in Australia. Attrition in tertiary online programs is a persistent problem. The significant developments in attrition theory that have occurred over the last three decades need to be more closely reflected upon and inform policy and practice in this area. In the context of synchronous technology, Rovai's model requires consideration of both Tinto's (1975) internal factors of academic and social integration, as well as Bean and Metzner's (1985)/Kember's (1989) external factors in developing a cohesive retention strategy.

The results of this study of a cohort of Australian undergraduate students studying law, fully online, support Bean and Metzner's (1985), and Kember's (1989) models. Work, as an external attrition risk factor, was a key driver in the decision to choose online study, and was a necessity accommodated by the flexibility of online study. Course and unit design and attrition strategies that fail to acknowledge significant external influences for students are at high risk of being suboptimal, and may increase attrition risk. The students' time poverty due to significant working hours also raises wellbeing issues that require further research.

The CQUniversity study does not support the assumption underpinning Bean and Metzner's (1985)/Kember's (1989) models', that students' internal social integration means little to non-traditional distance education students. As in Rush's (2015) study, the law students in this study were cognisant of the isolation inherent in their chosen mode of study. They sought better connection with their peers, albeit in a study-related, rather than informal or social, sense. This lends support to Rovai's (2003) assertion that Tinto's (1975) social integration risk factor continues to have currency for online learners.

Given the pressures of external attrition factors and academic focus of the cohort, addressing social integration via initiatives such as Facebook may prove difficult. Further research is required on the nature of student social isolation, and the means to address it. It may be that Tinto's (1975) faculty interaction is left to carry much of the responsibility for generating student institutional commitment. This paper identified a number of areas for further research, particularly regarding the role and nature of institutional commitment, and the need to develop suitable professional development programs for online teachers.

While the attrition risk issue is multi-faceted and complex, omitting reference to positive comments received under the survey invitation for further comments would be remiss. It is important to acknowledge that students' value online learning, and its role in achieving social equity objectives. This point was eloquently captured by the following respondents: "I am thoroughly enjoying my online learning experience and am grateful that this opportunity exists as there is absolutely no chance that I would be able 
to complete a degree without this opportunity" (Respondent 27) and, "Thank you for doing things differently. Being able to study in this way changes lives and possibilities" (Respondent 56). Comments such these deserve ongoing efforts, research, and innovation in the online learning environment.

\section{References}

Aldenderfer, M. S., \& Blashfield, R. K. (1984). Quantitative applications in the social sciences: Cluster analysis. SAGE Publications Inc. https://doi.org/10.4135/9781412983648

Alijohani, O. (2016). A comprehensive review of the major studies and theoretical models of student retention in higher education. Higher Education Studies, 6(2), 1-18. https://doi.org/10.5539/hes.v6n2p1

Bawa, P. (2016). Retention in online courses: Exploring issues and solutions - a literature review. $S A G E$ Open, January-March, 1-11. https://doi.org/10.1177/2158244015621777

Bazeley, P., \& Jackson, K. (2013). Qualitative data analysis with NVivo (2nd ed.). SAGE Publications Ltd.

Bean J. P., \& Metzner, B. S., (1985). A conceptual model of nontraditional student attrition. Review of Educational Research, 55(40), 485-540. https://doi.org/10.3102/00346543055004485

Bergmann, J., \& Sams, A. (2012). Flip your classroom: Reach every student in every class every day. ProQuest Ebook Central. https://ebookcentral.proquest.com/lib/cqu/detail.action?docID=3317690

Braun, V., Clarke, V., Hayfield, N., \& Terry, G. (2019). Thematic analysis. In P. Laimputong, (Ed.), Handbook of research methods in health social sciences (pp. 843-860). Springer. https://doi.org/10.1007/978-981-10-2779-6_103-1

Canon, R. (1983). The professional development of Australian university teachers: An act of faith? Higher Education, 12, 19-33. https://doi.org/10.1007/BF00140269

Cheng, L., Ritzhaupt, A. D., \& Antonenko, P. (2019). Effects of the flipped classroom instructional strategy on students' learning outcomes: A meta-analysis. Education Technology Research and Development, 67, 793-824. https://doi.org/10.1007/s11423-018-9633-7

Cherastidtham I., \& Norton, A. (2018). University attrition: What helps and what hinders university completion? Grattan Institute. https://grattan.edu.au/wp-content/uploads/2018/04/University-attritionbackground.pdf

Corbin, J., \& Strauss, A. (2008). Basics of qualitative research: Techniques and procedures for developing grounded theory. SAGE Publications Inc. https://doi.org/10.4135/9781452230153

Creswell, J. W., \& Miller, D. L. (2000). Determining validity in qualitative inquiry. Theory into Practice, 39(3), 125-130. https://doi.org/10.1207/s15430421tip3903 2

Dearn, J., Fraser, K., \& Ryan, Y. (2002). Investigation into the provision of professional development for university teaching in Australia: A discussion paper. Department of Education, Skills \& Training. https://www.researchgate.net/profile/Yoni Ryan/publication/240061881 Investigation into the Prov ision of Professional Development for University Teaching in Australia A/links/00b49538e6ade $\underline{28 f 56000000}$

Department of Education and Training. (2017). Improving retention, completion and success in higher education (Final Report D18/370395, 2017). Department of Education and Training, Higher Education Standards Panel. https://docs.education.gov.au/node/50816

Department of Education. (2019). Completion rates of higher education students: Cohort analysis, 20102018 (D19/1363980). Australian Government, Department of Education, Skills and Employment. https://docs.education.gov.au/node/53032

Durkheim, E. (1951). Suicide: A study in sociology. G. Simpson (Ed.), J. A. Spaulding, \& G. Simpson (Trans.), Routledge and Kegan Paul Ltd.

Eaton, G.C. (2019). Is utilization of university-sponsored social media associated with increased social integration and retention among online students? (Doctoral dissertation). Liberty University Doctoral Dissertations. https://digitalcommons.liberty.edu/cgi/viewcontent.cgi?article=3128\&context=doctoral

Expert Panel on Performance-Based Funding. (2019). Performance-based funding for the Commonwealth grant scheme (Report for the Minister of Education). Department of Education, Skills and Employment. https://docs.education.gov.au/system/files/doc/other/ed19-0134 - he- performancebased funding review acc.pdf

Fagioli, L. P., Rios-Aguilar, C., \& Deil-Amen, R. (2015). Changing the context of student engagement: Using Facebook to increase community college student persistence and success. Teachers College Record, 117(12), [18150]. https://www.scopus.com/record/display.uri?eid=2-s2.0$\underline{84951921077 \& \text { origin }=\text { inward\&txGid }=129605386 \mathrm{e} 67 \mathrm{c} 2 \mathrm{~d} 8300850 \mathrm{e} 4 \mathrm{a} 01 \mathrm{~d} 3 \mathrm{~d} 34}$ 
Filatova, O. (2016). More than a word cloud. TESOL Journal, 7(2), 438-448. https://doi.org/10.1002/tesj.251

Garrison, D. R., Anderson, T., \& Archer, W. (2000). Critical inquiry in a text-based environment: Computer conferencing in higher education. The Internet and Higher Education, 2(3), 87-105. https://doi.org/10.1016/S1096-7516(00)00016-6

George, A., McEwan, A., \& Tarr, J. (2018). Facebook: Bridging the otherness of distance legal education. Journal of the Australasian Law Teachers' Association, 11, 35-48. https://doi.org/10.13140/RG.2.2.19239.70564

Gregory, J., \& Salmon, G. (2013). Professional development for online university teaching. Distance Education, 34(3), 256-270. https://doi.org/10.1080/01587919.2013.835771

Kelk, N., Luscombe, G., Medlow, S., \& Hickie, I. (2010). Distress and depression among Australian law students: Incidence, attitudes and the role of universities. Sydney Law Review, 31(1), 113-122. http://www8.austlii.edu.au/cgi-bin/viewdoc/au/journals/SydLawRw/2010/5.html

Kember, D. (1989). A longitudinal-process model of drop-out from distance education. The Journal of Higher Education, 60(3), 278-301. https://doi.org/10.1080/00221546.1989.11775036

Kember, D. (1995). Open learning courses for adults: A model of student progress. Educational Technology Publications.

Lage, M. J., \& Platt, G. (2000). The internet and the inverted classroom. The Journal of Economic Education, 31(1), 11. https://doi.org/10.1080/00220480009596756

Lage, M. J., Platt, G. J., \& Treglia, M. (2000). Inverting the classroom: A gateway to creating an inclusive learning environment. The Journal of Economic Education, 31(1), 30-43. http://www.jstor.org/stable/1183338

Lewis, C. E. (2019). Is the flipped classroom a panacea for medical education? Current Surgery Reports 7, 9. https://doi.org/10.1007/s40137-019-0230-4

Lewis-Beck, M. S., Bryman, A., \& Futing Liao, T. (2004). Likert scale. In A. Bryman, M. LewisBeck, \& T. Liao (Eds.), The SAGE encyclopaedia of social science research methods. SAGE Publications Ltd. https://doi.org/10.4135/9781412950589.n495

Miley, F., \& Reid, A. (2011). Using word clouds to develop proactive learners. Journal of the Scholarship of Teaching and Learning, 11(2), 91-110. https://pdfs.semanticscholar.org/6e34/5606df0ff20ac92192eb640f7590a07ec9f5.pdf

Milheim, K. L. (2012). Toward a better experience: Examining student needs in the online classroom through Maslow's hierarchy of needs model. MERLOT Journal of Online Learning and Teaching, 8(2), 159-171. https://jolt.merlot.org/vol8no2/milheim 0612.htm

Moore, M. (1973). Toward a theory of independent learning and teaching. The Journal of Higher Education, 44(9), 661-679. https://doi.org/10.1080/00221546.1973.11776906

Rovai, A. P. (2002). Building a sense of community at a distance. International Review of Research in Open and Distance Learning, 3(1), 1-16. http://www.irrodl.org/index.php/irrodl/article/view/79

Rovai, A. P. (2003). In search of higher persistence rates in distance education online programs. Internet and Higher Education, 6(1), 1-16. https://doi.org/10.1016/S1096-7516(02)00158-6

Rovai, A. P., \& Downey, J., R. (2010). Why some distance education programs fail while others succeed in a global environment. Internet and Higher Education, 13(3) 141-147. https://doi.org/10.1016/j.iheduc.2009.07.001

Rush, P. (2015). Isolation and connection: The experience of distance education. International Journal of e-Learning and Distance Education, 30(2), http://www.ijede.ca/index.php/jde/article/view/936/1597

Sadowski, C., Pediaditis, M., \& Townsend, R. (2017). University students' perceptions of social networking sites (SNSs) in their educational experiences at a regional Australian university. Australasian Journal of Educational Technology, 33(5), 77-90. https://doi.org/10.14742/ajet.2927

Skead, N., \& Rogers. S. (2014). Stress, anxiety and depression in law students: How student behaviours affect student wellbeing. Monash University Law Review, 40(2), 564-587. https://www.monash.edu/_data/assets/pdf_file/0016/232504/skead.pdf

Spady, W. (1970). Dropouts from higher education: An interdisciplinary review and synthesis. Interchange, 1(1), 64-85. https://link.springer.com/article/10.1007/BF02214313

Spady, W. (1971). Dropouts from higher education: Toward an empirical model. Interchange, 2(3), 3862. https://doi.org/10.1007/BF02282469

Stone, C., \& O'Shea, S. (2019). Older, online and first: Recommendations for retention and success. Australasian Journal of Educational Technology, 35(1), 57-69. https://doi.org/10.14742/ajet.3913 
Sun, Z., Xie, K., \& Anderman, L. (2018). The role of self-regulated learning in students' success in flipped undergraduate math courses. The Internet and Higher Education, 36, 41-53. http://dx.doi.org/10.1016/j.iheduc.2017.09.003

Tehan, D. (2019). The future of Australian universities focuses on achievement. [Press release]. https://ministers.education.gov.au/tehan/future-australian-universities-focuses-achievement

Tertiary Education Quality and Standards Agency. (2017). Characteristics of Australian higher education providers and their relation to first-year student attrition (Discussion Paper). Department of Education, Skills and Employment. https://www.teqsa.gov.au/sites/default/files/attrition-report-june2017-19dec2017.pdf?v=1513650539

Tinto, V. (1975). Drop-out from higher education: A theoretical synthesis of recent research. Review of Educational Research, 45(1), 89-125. https://doi.org/10.3102/00346543045001089

Tinto, V. (1994). Leaving College: Rethinking the Causes and Cures of Student Attrition (2nd ed.). University of Chicago Press. https://press.uchicago.edu/ucp/books/book/chicago/L/bo3630345.html

Trespalacios, J., \& Lowenthal, P.J. (2019). What do they really like? An investigation of students' perceptions of their coursework in a fully online educational technology program. Australasian Journal of Educational Technology, 35(5), 60-78. https://doi.org/10.14742/ajet.4364

Voogt, J. (2003). Consequences of ICT for aims, contents, processes and environments of learning. In J. van den Akker, W. Kuiper, \& U. Hameyer (Eds.), Curriculum landscapes and trends (pp. 217-236). Kluwer.

Voogt, J. (2008). IT and curriculum processes: Dilemmas and challenges. In J. Voogt J., \& G. Knezek (Eds.), International handbook of information technology in primary and secondary education (pp. 117-132). Springer Science+Business Media.

Voogt, J., \& Roblin, N. (2012). A comparative analysis of international frameworks for 21st century competences: Implications for national curriculum policies. Journal of Curriculum Studies, 44(3), 299-321. https://doi-org.ezproxy.cqu.edu.au/10.1080/00220272.2012.668938

Wilson, G., \& Stacey, E. (2004). Online interaction impacts on learning: Teaching the teachers to teach online. Australasian Journal of Educational Technology, 20(1), 33-48. https://doi.org/10.14742/ajet.1366

Zhai, X., Gu, J., Liu, H., Liang, J. C., \& Tsai, C. C. (2017). An experiential learning perspective on students' satisfaction model in a flipped classroom context. Journal of Educational Technology \& Society, 20(1), 198-210. https://www.semanticscholar.org/paper/An-Experiential-LearningPerspective-on-Students'-a-Zhai-Gu/78e32704cc3447102be8a1e7773514cfa1c4104b

Corresponding author: Amanda-Jane George, a.m.george@cqu.edu.au

Copyright: Articles published in the Australasian Journal of Educational Technology (AJET) are available under Creative Commons Attribution Non-Commercial No Derivatives Licence (CC BY-NCND 4.0). Authors retain copyright in their work and grant AJET right of first publication under CC BYNC-ND 4.0.

Please cite as: George, A-J., McEwan, A., \& Tarr, J-A.. (2021). Accountability in educational dialogue on attrition rates: Understanding external attrition factors and isolation in online law school. Australasian Journal of Educational Technology, 37(1), 111-132. https://doi.org/10.14742/ajet.6175 


\section{Appendix A \\ The CQUniversity survey}

\section{Survey Instrument}

1. [Electronic consent to the survey]

2. Are you enrolled in the Bachelor of Laws online program at CQUniversity? -Yes/No

3. How long have you been studying in the Bachelor of Laws program?

4. Are you enrolled as a part-time or full-time student? -Part-time/Full time

5. Are you the first person in your family to study at a Higher Education Institution? -Yes/No

6. Do you work in paid employment as well as study law at a University? -Yes - take to question 7 -No - take to question 8

7. How many hours do you spend in paid employment per week?

-0 to 9 hours

-10 to 19 hours

-20 to 29 hours

-30 to 40 hours

-40 hours +

8. What is your household income level?

-on Government subsidy/allowance

$-\$ 18,001-\$ 37,000$

$-\$ 37,001-\$ 87,000$

$-\$ 87,001-\$ 180,000$

$-\$ 180,001+$

9. How old are you (in years)?

$18-25 ; 26-34 ; 35-44 ; 45-54 ; 55-64 ; 65$ and older

10. Are you?

-Male

-Female

-Other (specify)

11. Where do you live?

-I live in one of the five Major Capital Australian Cities (Sydney, Melbourne, Brisbane, Perth, Adelaide, Canberra)

-I live in a Regional City

-I live in a Rural Area

-I live in a Remote or very remote area

12. Were you born overseas, or do you consider your primary cultural background to be other than Australian? -Yes/No

13. Do you speak any other language than English? Please specify

14. Do you identify as having a disability? -Yes/No

15. Do you have any dependents? For example, are you a carer?

Yes - take to number of dependents Q16

No - take to Q17 
16. How many dependents do you have?

17. How would you describe your living circumstances? For example, I'm a single person living in a share house.

18. Which, if any, support services have you accessed so far while you have been enrolled as a student at -CQUniversity?

-Counselling

-Accessibility (eg exam support for disability, illness, medical or mental health)

-Student mentor program

-Indigenous student support

-Student advocacy

-Academic learning centre

-Financial assistance (eg CQUniversity student loan service)

-Careers advice

-None

19. What were your reasons for choosing to study law online?

20. If you had your choice again, would you choose to study law on campus in traditional face-to-face lecture mode?

-Yes/No

21. In general, how would you rate your quality of life?

5-point LIKERT scale. [Poor/Fair/Good/Very Good/Excellent]

22. If CQUniversity can assist you with counselling services, please contact them on 074930 9456, drop in to make an appointment or email counselling@cqu.edu.au.

-Ok, thanks [acknowledgment]

23. Overall, how connected do you feel to CQUniversity?

5-point LIKERT scale. [Not connected at all/A little bit connected/Somewhat connected/Quite connected/Strongly connected]

24. How connected do you feel to your student peers?

5-point LIKERT scale. [Not connected at all/A little bit connected/Somewhat connected/Quite connected/Strongly connected]

25. How connected do you feel to your lecturers?

5-point LIKERT scale. [Not connected at all/A little bit connected/Somewhat connected/Quite connected/Strongly connected]

26. What do you think is the best aspect of being a distance student?

27. What do you think is the worst aspect of being a distance student?

28. What would make distance learning better for you?

29. Any other comments 


\section{Appendix B}

The CQUniversity coding

\begin{tabular}{|c|c|c|c|c|}
\hline \multicolumn{5}{|c|}{ Q26: Best aspect } \\
\hline Parent code & Child codes & $\begin{array}{c}N \\
\text { parent }\end{array}$ & $\begin{array}{c}N \\
\text { child }\end{array}$ & $\begin{array}{l}\% \text { of } \\
\text { total }\end{array}$ \\
\hline \multirow[t]{5}{*}{ Flexibility } & & 183 & & 105.2 \\
\hline & Time, convenience & & 107 & 61.5 \\
\hline & Flexibility, unspecified reason & & 31 & 17.8 \\
\hline & Location, less or no travel & & 24 & 13.8 \\
\hline & Technology & & 21 & 12.1 \\
\hline \multirow[t]{5}{*}{ Necessity } & & 72 & & 41.4 \\
\hline & Work time & & 31 & 17.8 \\
\hline & Necessity, unspecified reason & & 20 & 11.5 \\
\hline & Family time & & 17 & 9.8 \\
\hline & Location, less or no travel & & 4 & 2.3 \\
\hline \multirow[t]{4}{*}{ Self-determination } & & 43 & & 24.7 \\
\hline & Self-paced & & 22 & 12.6 \\
\hline & Self-reliance, discipline, independence & & 8 & 4.6 \\
\hline & Control of life, goals, finding balance & & 13 & 7.5 \\
\hline Financial, less expense & & 7 & & 4.0 \\
\hline \multirow[t]{3}{*}{ Relations } & & 11 & & 6.3 \\
\hline & Good level of interaction, relations, positive & & 7 & 4.0 \\
\hline & Little interaction, positive & & 4 & 2.3 \\
\hline Resources & & $\overline{86}$ & & 3.5 \\
\hline None, negatives & & 4 & & 2.3 \\
\hline
\end{tabular}

Note. Codes corresponding to Rush's (2015) study are shaded

\begin{tabular}{|c|c|c|c|c|c|c|c|c|}
\hline \multicolumn{9}{|c|}{ Q27: Worst aspect } \\
\hline Parent code & Child codes & $\begin{array}{l}\text { Grandchild } \\
\text { codes }\end{array}$ & $\begin{array}{l}\text { Great- } \\
\text { grandchild } \\
\text { codes }\end{array}$ & $\begin{array}{c}N \\
\text { parent }\end{array}$ & $\begin{array}{c}N \\
\text { child }\end{array}$ & $\begin{array}{c}N \\
\text { G/- } \\
\text { child }\end{array}$ & $\begin{array}{l}N \\
\text { GG/- } \\
\text { child }\end{array}$ & $\begin{array}{l}\% \text { of } \\
\text { total }\end{array}$ \\
\hline \multirow[t]{9}{*}{ Isolation } & & & & 195 & & & & 112.1 \\
\hline & Disconnection & & & & 130 & & & 74.7 \\
\hline & & $\begin{array}{l}\text { Disconnected } \\
\text { - social, peers }\end{array}$ & & & & 76 & & 43.7 \\
\hline & & & $\begin{array}{l}\text { Peer-- } \\
\text { social }\end{array}$ & & & & 15 & 8.6 \\
\hline & & & $\begin{array}{l}\text { Peer - } \\
\text { study }\end{array}$ & & & & 19 & 10.9 \\
\hline & & & $\begin{array}{l}\text { Peer - } \\
\text { unspecified }\end{array}$ & & & & 40 & 22.9 \\
\hline & & & $\begin{array}{l}\text { Lack social } \\
\text { media }\end{array}$ & & & & 2 & 1.1 \\
\hline & & $\begin{array}{l}\text { Disconnected } \\
\text { - lecturers }\end{array}$ & & & & 26 & & 14.9 \\
\hline & & $\begin{array}{l}\text { Disconnected } \\
\text { - institution }\end{array}$ & & & & 5 & & 2.9 \\
\hline
\end{tabular}




\begin{tabular}{|c|c|c|c|c|c|c|}
\hline & & $\begin{array}{l}\text { Disconnection, } \\
\text { - unspecified }\end{array}$ & & & 23 & 13.2 \\
\hline & $\begin{array}{l}\text { Lack of co- } \\
\text { location }\end{array}$ & & & 51 & & 29.3 \\
\hline & & $\begin{array}{l}\text { Lack of face- } \\
\text { to-face } \\
\text { contact, in } \\
\text { classroom } \\
\text { lectures }\end{array}$ & & & 37 & 21.3 \\
\hline & & $\begin{array}{l}\text { Learning is } \\
\text { harder because } \\
\text { of lack of } \\
\text { physical co- } \\
\text { location }\end{array}$ & & & 14 & 8.0 \\
\hline & $\begin{array}{l}\text { Slow or no } \\
\text { responsiveness }\end{array}$ & & & 9 & & 5.2 \\
\hline & $\begin{array}{l}\text { Lack } \\
\text { professional } \\
\text { networking, } \\
\text { opportunities }\end{array}$ & & & 5 & & 2.9 \\
\hline Responsibility & & & 34 & . & & 19.5 \\
\hline & Motivation & & & 15 & & 8.6 \\
\hline & & $\begin{array}{l}\text { Motivation, } \\
\text { self- } \\
\text { motivation }\end{array}$ & & & 11 & 6.3 \\
\hline & & $\begin{array}{l}\text { Lack of } \\
\text { engagement }\end{array}$ & & & 4 & 2.3 \\
\hline & $\begin{array}{l}\text { Self-regulation, } \\
\text { discipline, self- } \\
\text { reliance }\end{array}$ & & & 19 & & 10.9 \\
\hline Resources & & & 14 & & & 8.0 \\
\hline & $\begin{array}{l}\text { Difficulty } \\
\text { accessing } \\
\text { libraries, } \\
\text { textbooks or } \\
\text { lack of } \\
\text { resources }\end{array}$ & & & 4 & & 2.3 \\
\hline & $\begin{array}{l}\text { Low quality or } \\
\text { confusing }\end{array}$ & & & 4 & & 2.3 \\
\hline & $\begin{array}{l}\text { Technical } \\
\text { problem }\end{array}$ & & & 6 & & 3.4 \\
\hline Unconsidered & & & 27 & & & 15.5 \\
\hline & $\begin{array}{l}\text { Not being able } \\
\text { to } \\
\text { self-pace, } \\
\text { scheduling, etc. }\end{array}$ & & & 19 & & 10.9 \\
\hline & & Group work & & & 9 & 5.2 \\
\hline & & $\begin{array}{l}\text { Invigilated } \\
\text { exams }\end{array}$ & & & 7 & 4.0 \\
\hline & & $\begin{array}{l}\text { Daytime } \\
\text { lectures, } \\
\text { assignments }\end{array}$ & & & 3 & 1.7 \\
\hline
\end{tabular}




\begin{tabular}{|l|l|l|r|r|r|r|r|r|}
\hline & $\begin{array}{l}\text { Costs, not same } \\
\text { value }\end{array}$ & & & & & & & \\
\hline & $\begin{array}{l}\text { Lack of lecturer } \\
\text { flexibility, } \\
\text { support }\end{array}$ & & & & 6 & & & 3.4 \\
\hline \hline Relations & & & & 8 & & & & 4.6 \\
\hline & $\begin{array}{l}\text { Distractions } \\
\text { (peers and } \\
\text { others) }\end{array}$ & & & & 6 & & & 3.4 \\
\hline & $\begin{array}{l}\text { Communication } \\
\text { issues }\end{array}$ & & & & 2 & & & 1.1 \\
\hline \hline $\begin{array}{l}\text { None, nil, } \\
\text { satisfied }\end{array}$ & & & & 15 & & & & 8.6 \\
\hline Other & & & & 4 & & & & 2.3 \\
\hline
\end{tabular}

Note. Codes corresponding to Rush's (2015) study are shaded

\begin{tabular}{|c|c|c|c|c|c|c|c|c|}
\hline \multicolumn{9}{|c|}{ Q28: Making it Better } \\
\hline Parent code & Child codes & $\begin{array}{l}\text { Grandchild } \\
\text { codes }\end{array}$ & $\begin{array}{l}\text { Great- } \\
\text { grandchild } \\
\text { codes }\end{array}$ & $\begin{array}{c}N \\
\text { parent }\end{array}$ & $\begin{array}{c}N \\
\text { child }\end{array}$ & $\begin{array}{c}N \\
\text { G/child }\end{array}$ & $\begin{array}{c} \\
\text { GG/ } \\
\text { child }\end{array}$ & $\begin{array}{l}\% \text { of } \\
\text { total }\end{array}$ \\
\hline \multirow[t]{10}{*}{ More contact } & & & & 69 & & & & 41.8 \\
\hline & $\begin{array}{l}\text { More } \\
\text { contact - } \\
\text { physical }\end{array}$ & & & & 29 & & & 17.6 \\
\hline & $\begin{array}{l}\text { More } \\
\text { contact - } \\
\text { online }\end{array}$ & & & & 7 & & & 4.2 \\
\hline & $\begin{array}{l}\text { More } \\
\text { interactions }\end{array}$ & & & & 33 & & & 20.0 \\
\hline & & $\begin{array}{l}\text { More } \\
\text { mentors, } \\
\text { orientation, } \\
\text { familiarisation }\end{array}$ & & & & 7 & & 4.2 \\
\hline & & $\begin{array}{l}\text { More lecturer } \\
\text { interaction }\end{array}$ & & & & 6 & & 3.6 \\
\hline & & $\begin{array}{l}\text { More student } \\
\text { interaction }\end{array}$ & & & & 20 & & 12.1 \\
\hline & & & $\begin{array}{l}\text { More } \\
\text { student } \\
\text { interaction, } \\
\text { unspecified }\end{array}$ & & & & 8 & 4.8 \\
\hline & & & $\begin{array}{l}\text { More } \\
\text { student } \\
\text { interaction, } \\
\text { social }\end{array}$ & & & & 2 & 1.2 \\
\hline & & & $\begin{array}{l}\text { More } \\
\text { student } \\
\text { interaction, } \\
\text { study- } \\
\text { focused }\end{array}$ & & & & 10 & 6.1 \\
\hline
\end{tabular}




\begin{tabular}{|c|c|c|c|c|c|c|}
\hline Consideration & & & 50 & & & 30.3 \\
\hline & $\begin{array}{l}\text { No group } \\
\text { assignments }\end{array}$ & & & 7 & & 4.2 \\
\hline & Exams & & & 16 & & 9.7 \\
\hline & $\begin{array}{l}\text { Staffing } \\
\text { issues }\end{array}$ & & & 27 & & 16.4 \\
\hline & & $\begin{array}{l}\text { Better } \\
\text { scheduling, } \\
\text { flexibility }\end{array}$ & & & 14 & 8.5 \\
\hline & & $\begin{array}{l}\text { Better } \\
\text { feedback, } \\
\text { guidance }\end{array}$ & & & 13 & 7.9 \\
\hline Positive & & & 23 & & & 13.9 \\
\hline Resources & & & 23 & & & 13.9 \\
\hline $\mathrm{N} / \mathrm{A}$, unsure & & & 20 & & & 12.1 \\
\hline $\begin{array}{l}\text { Cost, } \\
\text { financial }\end{array}$ & & & 11 & & & 6.7 \\
\hline Personal & & & 9 & & & 5.5 \\
\hline
\end{tabular}

Note. Codes corresponding to Rush's (2015) study are shaded 